\begin{tabular}{|c|c|}
\hline & Asian Social Work Journal (ASWJ) \\
\hline $\begin{array}{c}\text { ASIAN SOCIAL WORK } \\
\text { JOURAL } \\
\text { (ASW) }\end{array}$ & Volume 3, Issue 3, July 2018 \\
& e-ISSN : 0128-1577 \\
& Journal home page: \\
& www.msocialwork.com \\
\hline
\end{tabular}

\title{
Pekerjaan Sosial Sebagai Disiplin Ilmu dan Profesi
}

\author{
Adi Fahrudin 1 \\ 1Universitas Muhammadiyah Jakarta \\ 1Visiting Professor \& Research Fellow, Universiti Malaysia Sabah (UMS) \\ 1Visiting Professor, Social Work Research Institute, Japan College of Social Work \\ Corrrespondence: Adi Fahrudin (fahradi@gmail.com)
}

\begin{abstract}
Abstrak
Pekerjaan sosial merupakan disiplin akademik dan profesi berbasis praktek. Sebagai disiplin akademik, pekerjaan sosial ditunjang oleh teori-teori yang bersumber dari pekerjaan sosial itu sendiri, ilmu sosial dan ilmu lain yang relevan. Hal ini menegaskan bahwa pekerjaan sosial merupakan ilmu sosial terapan yang sekaligus sebuah profesi. Untuk dapat dikatakan sebuah profesi maka pekerjaan sosial harus dipraktekkan. Oleh sebab itu pekerjaan sosial tidak hanya dipelajari sebagai disiplin akademik melainkan harus dipraktikkan. Praktik tanpa dilandasi disiplin akademik tidak terarah, disiplin akademik tanpa praktik tidak lebih dari sekedar wacana.
\end{abstract}

Kata kunci: pekerjaan sosial, disiplin akademik, profesi, praktek

\begin{abstract}
Social work is an academic discipline and practice -based profession. As an academic discipline, social work is supported by theories derived from social work itself, social sciences and other relevant sciences. This confirm that social work is an applied social science that is at once a profession. To be considered a profession that social work should be practiced. Therefore, social work not only studied as an academic discipline but must be practiced. Practice without based on academic disciplines not directed and could be fraudulent, academic disciplines without practice is nothing more than discourse.
\end{abstract}

Key words: social work, academic discipline, profession, practice

\section{Pengenalan}

Tulisan ini disarikan dari naskah pidato pengukuhan saya sebagai guru besar/profesor dalam ilmu pekerjaan sosial. Sebagai orang Indonesia pertama yang dikukuhkan sebagai guru besar/profesor Ilmu Pekerjaan Sosial, saya punya kewajiban untuk menjelaskan bagaimana pekerjaan sosial sebagai disiplin ilmu dan profesi. Mengawali tulisan ini saya mengajukan hipotesis berkenaan dengan pekerjaan sosial di Indonesia saat ini, yaitu apakah pekerjaan sosial (social work) itu sebuah disiplin ilmu ? Kalau Ya, bagaimana penjelasan logis sebagai sebuah disiplin ilmu (terapan), selanjutnya apakah pekerjaan sosial dikatakan sebagai sebuah profesi? Kemudian apakah pekerja sosial di Indonesia sudah profesional? Kalau Ya, bagaimana kadar profesionalisme pekerja sosial dimaksud? Pertanyaan ini kedengaran sederhana bagi orang yang menekuni disiplin dan profesi ini, tapi tidak bagi orang di luar disiplin dan 
profesi pekerjaan sosial. Mereka kritis mempertanyakan kedudukan pekerjaan sosial sebagai sebuah disiplin ilmu dan status sebagai profesi dalam masyarakat. Melalui tulisan ini diharapkan dapat menjelaskan keraguan dan kesimpangsiuran mengenai disiplin dan profesi pekerjaan sosial.

\section{Tafsir Tentang Pekerjaan Sosial}

Salah satu fungsi Perguruan Tinggi (untuk selanjutnya disebut sekolah) yang membuka jurusan Pekerjaan Sosial adalah mendidik dan melatih para mahasiswa untuk menjadi calon pekerja sosial. Pekerja sosial adalah orang yang melaksanakan pekerjaan sosial sebagai profesi. Jadi pekerja sosial yang dibicarakan di sini adalah pekerja sosial profesional, yaitu mereka yang telah mengikuti pendidikan pekerjaan sosial di suatu lembaga pendidikan tinggi pekerjaan sosial terakreditasi.

Pekerjaan sosial sebagai profesi tidak sama dengan pengertian pekerjaan sosial secara awam. Menurut pengertian awam semua perbuatan baik untuk orang lain sudah dikatakan pekerjaan sosial. Sebagai contoh, misalnya memberi uang kepada pengemis, anak jalanan dan semacamnya, memberikan sumbangan untuk tetangga yang mengalami musibah atau untuk korban bencana alam, menolong orang yang sakit, dan kegiatan-kegiatan lain semacam itu acapkali sudah dianggap pekerjaan sosial.

Studi mengenai kurikulum yang disponsori oleh the Council on Social Work Education di Amerika Serikat dalam tahun 1959 menyatakan bahwa "Social work seeks to enhance the social functioning of individuals, singly and in groups, by activities focused upon their social relationships which constitute the interaction between man and his environment. These activities can be grouped into three functions: restoration of impaired capacity, provision of individual and social resources, and prevention of social dysfunction" (Farley et al., 2003:4).

Artinya: pekerjaan sosial berusaha untuk meningkatkan keberfungsian sosial individu, secara sendirisendiri atau dalam kelompok, dengan kegiatan-kegiatan yang dipusatkan pada interaksi sosial mereka yang merupakan interaksi antara orang dan lingkungannya. Kegiatan-kegiatan ini dapat dikelompokkan menjadi tiga fungsi: pemulihan kemampuan yang terganggu, penyediaan sumber-sumber individu dan sosial, dan pencegahan disfungsi sosial.

Asosiasi Nasional Pekerja Sosial Amerika Serikat (National Association of Social Workers) merumuskan pekerjaan sosial sebagai berikut "Social work is the professional activity of helping individuals, groups, or communities to enhance or restore their capacity for social functioning and to create societal conditions favorable to their goals. Social work practice consists of the profesional application of social work values, principles, and techniques to one or more of the following ends: helping people obtain tangible services; providing counseling and psychotherapy for individuals, families, and groups; helping communities or groups provide or improve social and health services; and participating in relevant legislative processes (NASW, 2013).

Artinya: Pekerjaan sosial adalah kegiatan profesional membantu individu, kelompok, atau masyarakat untuk meningkatkan atau memulihkan kemampuan mereka berfungsi sosial dan untuk menciptakan kondisi sosial yang mendukung tujuan-tujuan ini. Praktik pekerjaan sosial terdiri atas penerapan profesional dari nilai-nilai, prinsip-prinsip, dan teknik-teknik pekerjaan sosial pada satu atau lebih dari tujuan-tujuan berikut: membantu orang memeroleh pelayanan-pelayanan nyata; memberikan konseling dan psikoterapi untuk individu-individu, keluarga-keluarga, dan kelompok-kelompok; membantu komunitas atau kelompok memberikan atau memerbaiki pelayanan-pelayanan sosial dan kesehatan; dan ikut serta dalam proses-proses legislatif yang berkaitan. Praktik pekerjaan sosial memerlukan pengetahuan tentang perkembangan dan perilaku manusia; tentang institusi-institusi sosial, ekonomi, dan kultural; dan tentang interaksi antara semua faktor ini.

Siporin (1975) pula mendefinisikan pekerjaan sosial sebagai berikut: "Social work is defined as a social institutional method of helping people to prevent and to resolve their social problems, to restore and enhance their social functioning." (hal. 3). Pekerjaan sosial didefinisikan sebagai metode kelembagaan sosial untuk membantu orang untuk mencegah dan memecahkan masalah-masalah sosial 
mereka, untuk memulihkan dan meningkatkan keberfungsian sosial mereka. Lebih lanjut Siporin menyatakan bahwa pekerjaan sosial adalah suatu institusi sosial, suatu profesi pelayanan manusia, dan suatu seni praktik teknis dan ilmiah. Dalam meta-institusi kesejahteraan sosial, pekerjaan sosial memunyai posisi pokok dan sejumlah fungsi dasar yang merupakan tugas-tugas kemasyarakatan. Fungsi-fungsi inti dan pelayanan-pelayanan pertolongan khusus dalam sistem kesejahteraan sosial dilaksanakan oleh anggota-anggota profesi pekerjaan sosial dalam bentuk apa yang disebut sebagai praktik pekerjaan sosial.

Pada tahun 2010, the International Federation of Social Workers (IFSW) dan diterima oleh International Association of Schools of Social Work (IASSW) dan International Council on Social Welfare (ICSW) merilis definisi definisi global mengenai pekerjaan sosial adalah sebagai berikut: "The social work profession promotes social change, problem solving in human relationships and the empowerment and liberation of people to enhance well-being. Utilising theories of human behaviour and social systems, social work intervenes at the points where people interact with their environments. Principles of human rights and social justice are fundamental to social work. (IFSW, 2013).

Artinya: Profesi pekerjaan sosial mempromosikan perubahan sosial, pemecahan masalah dalam hubungan-hubungan manusia serta pemberdayaan dan pembebasan orang untuk meningkatkan kesejahteraan. Dengan menggunakan teori-teori perilaku manusia dan sistem sosial, pekerjaan sosial melakukan intervensi pada titik-titik tempat orang berinteraksi dengan lingkungannya. Prinsip-prinsip hak azasi manusia dan keadilan sosial merupakan dasar bagi pekerjaan sosial.

Dalam hal ini pekerjaan sosial juga dilaksanakan dalam berbagai cara untuk mengatasi masalah transaksi antara manusia dengan lingkungan sosial yang kompleks dan berbagai. Misinya adalah memungkinan semua orang dapat mengembangkan potensinya secara penuh, memperkaya kehidupan mereka, dna mencegah terjadinya disfungsi sosial. Pekerjaan sosial professional fokus pada pemecahan masalah dan perubahan, termasuk diantaranya pekerja sosial bertindak sebagai agen perubahan (agent of change) dalam masyarakat dan dalam kehidupan individu, keluarga dan masyarakat yang mereka layani. Intinya pekerjaan sosial adalah interelasi sistem nilai-nilai, teori dan praktek. Namun demikian, IFSW General Meeting and the IASSW General Assembly pada bulan Juli 2014 di Melbourne Australia melakukan reformasi mengenai definisi pekerjaan sosial secara global menjadi sebagai berikut" "Social work is a practice-based profession and an academic discipline that promotes social change and development, social cohesion, and the empowerment and liberation of people. Principles of social justice, human rights, collective responsibility and respect for diversities are central to social work. Underpinned by theories of social work, social sciences, humanities and indigenous knowledge, social work engages people and structures to address life challenges and enhance wellbeing" (IFSW, 2015). Pengertian ini sangat gamblang dan tegas menyatakan bahwa pekerjaan sosial merupakan disiplin akademik dan profesi berbasis praktek yang mempromosikan perubahan sosial dan pembangunan, kohesi sosial, dan pemberdayaan serta pembebasan orang. Berbeda dengan definisi sebelumnya, definisi terbaru ini lebih menonjolkan tanggungjawab kolektif dan penghormatan terhadap kebinekaan menjadi sesuatu yang sentral dalam pekerjaan sosial. Selain itu definisi terbaru ini menegaskan bahwa pekerjaan sosial sebagai disiplin akademik bersumber dari teori-teori pekerjaan sosial itu sendiri dan teori-teori yang bersumber dari ilmu sosial dan kemanusiaan tetapi juga mengakui kontribusi pengetahuan lokal (indigenus) yang berasal dari masyarakat di mana pekerjaan sosial dipraktikkan. Kemudian esensi akhirnya adalah bukan untuk mengatasi permasalahan melainkan tantangan kehidupan dan meningkatkan kesejahteraan manusia.

Kelima definisi tersebut sengaja saya paparkan dengan maksud untuk menggambarkan apa pekerjaan sosial itu. Definisi-defini menunjukkan pekerjaan sosial dalam menghadapi abad ke 21 adalah dinamik dan terus berkembang sesuai dengan perkembangan masyarakat dan dunia. Tetapi tentu saja masingmasing definisi tadi belum dapat menggambarkan apakah pekerjaan sosial itu merupakan suatu disiplin ilmu. 


\section{Pekerjaan Sosial Sebagai Disiplin Akademik}

Hampir selama 40 tahun lebih energi komunitas pekerjaan sosial di Indonesia dihabiskan dalam perdebatan mengenai ilmu antara pekerjaan sosial dan kesejahteraan sosial. Perdebatan kadangkala tidak lagi berdasarkan metodologi ilmiah keilmuan melainkan sudah mengarah kepada kubu, aliran dan kelompok. Banyak pihak menganggap pekerjaan sosial sebagai ilmu manakala kesejahteraan sosial merupakan bidang pelayanan atau kondisi sejahtera. Tidak sedikit pula yang mengganggap kesejahteraan sosial sebagai ilmu manakala pekerjaan sosial dianggap sebagai sub disiplin ilmu di dalamnya bahkan hanya keterampilan dalam bidang kesejahteraan sosial. Perdebatan ini selain mubazir juga mempengaruhi diskusi ilmiah yang selalu diulang dan diulang mempersoalkan peranan dan eksistensi profesi pekerjaan sosial dalam masyarakat, sehingga melupakan diskusi ilmiah mengenai metodologi, penelitian ilmiah, pengembangan keterampilan, indigenisasi, dan pengembangan modelmodel praktek yang sesuai dalam konteks lokal.

Dalam The Social Work Dictionary, bahkan dikatakan bahwa kesejahteraan sosial itu sebagai " $a$ nation's system of programs, benefits, and services that help people meet those social, economic, educational, and health needs that are fundamental to the maintenance of society"(Barker, 1987). Sebaliknya Zastrow (1999) mengatakan bahwa social welfare is more global term which encompasses social work. Social welfare and social work are primarily related at the level of practice. ... The term 'social worker' is usually applied to employed professionals who are graduates (either at the bachelor's, master's or PhD level) from schools of social work. Almost all social workers are employed in the field of social welfare" (hal.5).

Selain itu, hal ini dipertegas lagi oleh Hoffer (1960) yang mengatakan sebagai berikut "If social welfare is reserved for describing the field of work or services, then 'social work' could be used to designate the major professional core of social welfare". Jika kesejahteraan sosial digunakan untuk menjelaskan bidang pekerjaan atau pelayanan, maka pekerjaan sosial dapat digunakan untuk menunjukkan profesional utama dalam kesejahteraan sosial. Pendapat yang sama menyatakan bahwa pekerjaan sosial berminat kepada keberfungsian sosial dan hubungan antara klien dengan lingkungan sosialnya serta berusaha memanfaatkan sumber-sumber yang ada di dalam masyarakat guna memenuhi keperluan dan memecahkan permasalahan klien (personal maupun social) [Skidmore \& Thackeray, 1999).

Peletakan dasar keilmuan pekerjaan sosial sebagai disiplin ilmu telah dimulai pada tahun 1921 ketika Mary E Richmond menulis pengalaman prakteknya melayani gelandangan, pengemis dan orang-orang cacat ke dalam sebuah buku yang sangat dipengaruhi aliran Freudian ketika itu yaitu "Social Diagnosis" dan juga dianggap sebagai cikal bakal lahirnya metode social case work yang tak lain pekerjaan sosial tradisional yang kemudian berlanjut perkembangannya menjadi pekerjaan sosial yang modern dan dinamis sehingga kini (Richmond, 1917).

Penjelasan itu masih tidak memuaskan karena di Amerika Serikat dan di Eropah, para ahli menghindari perdebatan mengenai dua terminologi di atas. Namun hal ini sedikit berubah ketika pada tahun 2000 yang kemudian dipertegas lagi pada tahun 2014, IASSW dan IFSW mengeluarkan pengertian global mengenai pekerjaan sosial yaitu social work is a practice-based profession and an academic discipline that promotes social change and development, social cohesion, and the empowerment and liberation of people. Pengertian ini menekankan bahwa pekerjaan sosial sebagai disiplin akademik yang didasari oleh teori-teori pekerjaan sosial itu sendiri dan ilmu-ilmu sosial dan ilmu lain yang berkaitan. Pengertian ini sesungguhnya menegaskan bahwa pekerjaan sosial sebagai disiplin akademik merupakan disiplin ilmu terapan (applied science) karena menggunakan selain teori yang bersumber dari pekerjaan sosial sendiri tetapi juga menggunakan teori yang bersumber dari disiplin ilmu sosial dan ilmu-ilmu lain yang relevan seperti teori tingkah laku manusia dan sistem sosial.

Dengan menggunakan methatheoritical framework dari Souflee (1993) bahwa kontruksi pekerjaan sosial sebagai ilmu terapan bisa dijabarkan ke dalam beberapa unsur yaitu professional ideology, teleology, epistemology dan technology. Ideologi profesional bahkan menjangkau lebih dari sekedar nilai-nilai profesional, dan merujuk kepada sistem keyakinan dan sikap, pengekspresian nilai moral dan 
ideal mengenai hubungan antar manusia dan masyarakat, yang memotivasi orang bertindak guna merealisasikan nilai dan transformasi masyarakat (Siporin, 1975). Ideologi pekerjaan sosial meliputi faslafah humanistic, dan seperangkat nilai mengenai perilaku manusia, kehidupan dan budaya serta bersinggungan dengan kondisi manusia yang berkesejahteraan dan berkeadilan sosial. Ideologi professional ini pula yang kemudian diderivasi ke dalam nilai dan prinsip etika pekerjaan sosial. Sementara itu unsur teleologi adalah seperangkat nilai (value), tujuan (purpose), pengetahuan (knowledge) dan teknik (techniques). Dalam hal ini teleologi digambarkan ke dalam misi, maksud, tujuan dan fungsi dari profesi pekerjaan sosial. Bahkan oleh Beckner's (1967) kontruk teleologi diartikan lebih dari sekedar tujuan melainkan merujuk kepada aktivitas bertujuan (purposive activity) yang pada akhirnya mencerminkan identitas profesi. Sedangkan unsur epistemology menurut Souflee (1993) berbeda unsur dengan apa yang telah dikemukakan oleh Bartlett's (1958) dan Gordon (1962) dimana di dalamnya terkandung tidak hanya unsur pengetahuan tapi juga konsep teori dan verifikasi pengetahuan (how we know that what we know is true). Dengan kata lain, komponen pengetahuan dalam definisi pekerjaan sosial telah ditinggikan dalam kontruk epistemology, termasuk di dalamnya pengetahuan mengenai perilaku individu, kelompok, organisasi dan masyarakat. Itu sebabnya Siporin (1975) menjelaskannya sebagai pengetahuan yang terorganisasi (organized knowledge) yang itu tak lain adalah teori yang berkaitan dengan konsep dan proposisi mengenai realitas yang dikembangkan melalui peelitian oleh disiplin pekerjaan sosial sendiri atau yang diambil dari disiplin ilmu yang lain. Galbraith (1967) dalam artikelnya yang dikutip oleh Souflee (1993) mengatakan bahwa teknologi adalah "the systematic application of scientific or other orgized knowledge to practical tasks (hal.2), atau meminjam pengertian yang disampaikan oleh Taylor (1971) sebagai seperangkat prinsip-prinsip dan teknik-teknik yang digunakan untuk membawa perubahan. Dengan demikian, teknologi pekerjaan sosial diturunkan dari teori dan pengetahuan yang terorganisasi mengenai perilaku manusia dan perubahannya. Teknologi pekerjaan sosial itu menurut Bartlett (1958) sebagai 'method' atau istilah Gordon (1962) sebagai teknik atau istilah Siporin (1975) sebagai intervensi. Dan teknologi pekerjaan sosial menurut Stone (1979) bukanlah bersumber dari apa yang disebut "fallible" knowledge yaitu pengetahuan yang diperoleh hanya melalui kegigihan, diperoleh dari kebiasaan melakukan, atoritas atau intuisi. Teknologi pekerjaan sosial seharusnya didasarkan pada evidence based practice yang tak lain mengandalkan penelitian ilmiah.

Untuk mendukung pendapat saya di atas, saya kutipan informasi dalam UU No. 12 Tahun 2012 tentang Pendidikan Tinggi, khususnya pada Paragraf 2 Pasal 10 ayat 2 dinyatakan tentang Rumpun Ilmu Pengetahuan dan Teknologi terdiri atas; rumpun ilmu agama; rumpun ilmu humaniora; rumpun ilmu sosial; rumpun ilmu alam; rumpun ilmu formal; dan rumpun ilmu terapan. Dalam penjelasan UU tersebut tegas dinyatakan bahwa rumpun Ilmu Terapan merupakan rumpun Ilmu Pengetahuan dan Teknologi yang mengkaji dan mendalami aplikasi ilmu bagi kehidupan manusia antara lain pertanian, arsitektur dan perencanaan, bisnis, pendidikan, teknik, kehutanan dan lingkungan, keluarga dan konsumen, kesehatan, olahraga, jurnalistik, media massa dan komunikasi, hukum, perpustakaan dan permuseuman, militer, administrasi publik, kerja sosial, dan transportasi.

Berdasarkan penjelasan di atas, jelas bahwa pekerjaan sosial merupakan ilmu terapan. Hal ini karena pekerjaan sosial didalamnya terkandung ilmu pengetahuan dan teknologi, dan jika merujuk kepada kerangka metateori dari Souflee tadi maka pekerjaan sosial telah memenuhi kriteria dan unsur ideology, teleology, epistemology, dan technology. Keempat unsur ini saling berkaitan satu sama lain yang menunjukkan pristege sebuah disiplin ilmu terapan dan profesi pertolongan kemanusiaan. Dengan demikian seharusnya program studi yang ditawarkan di Perguruan Tinggi bukan Kesejahteraan Sosial melainkan Pekerjaan Sosial sepertimana di negara-negara lain meskipun nama Departemen/Jurusan di Perguruan Tinggi masih menggunakan Kesejahteraan Sosial. Secara logika sederhana, masyarakat awam bisa memahami bahwa mahasiswa kuliah pada jurusan Pekerjaan Sosial untuk menjadi pekerja sosial, seperti halnya mahasiswa kuliah pada jurusan kedokteran untuk menjadi dokter, kuliah pada jurusan keperawatan untuk menjadi perawat. Dengan menggunakan bahasa kiasan, bagaimana mungkin seekor rusa mampu mengasuh anak kuda agar menjadi kuda dewasa yang terampil dan siap menghadapi tantangan kehidupan. Ini soal 'core' pendidikan professional pekerjaan sosial, tentu tidak bermakna bahwa disiplin ilmu dan profesi pekerjaan sosial tidak memerlukan dukungan disiplin dan profesi lain, terlebih dalam pelaksanaan tugas pekerja sosial seringkali bersifat antar disiplin dan lintas disiplin. 


\section{Pekerjaan Sosial Sebagai Profesi}

Menurut Oxford Advanced Learner's Dictionary, profession adalah "a paid occupation, especially one that requires advanced education and training." (Hornby, 1995:924). Profesi adalah pekerjaan yang dibayar, dan profesi itu memerlukan pendidikan dan pelatihan lanjut. Dan menurut Webster's New Universal Unabridged Dictionary (1983), profession adalah "a vocation or occupation requiring advanced training in some liberal art or science, and usually involving mental rather than manual work." (hal.1437). Profesi adalah pekerjaan yang memerlukan pelatihan lanjut dalam suatu bidang pengetahuan budaya atau sains, dan biasanya yang melibatkan kerja mental ketimbang kerja tangan. Jadi profesi adalah pekerjaan yang memerlukan pendidikan tinggi sebagai landasannya. Tidak setiap pekerjaan yang menghasilkan uang adalah profesi. Kesalahan penggunaan kata profesi dalam kehidupan sehari-hari adalah misalnya digunakan untuk tukang beca, sopir angkutan, pedagang, dan bahkan juga digunakan untuk pekerja seks komersial.

Berdasarkan pengertian di atas, jelas pekerjaan-pekerjaan itu dan semacamnya bukanlah profesi. Hal ini akan lebih jelas lagi kalau kita membicarakan kriteria profesi. Dalam tahun 1915 Abraham Flexner dalam Konferensi tentang Amal dan Koreksi di Baltimore memertanyakan apakah pekerjaan sosial suatu profesi. Berdasarkan kriteria yang digunakannya, Flexner berkesimpulan bahwa pekerjaan sosial belum merupakan suatu profesi. Hal ini tentu saja membuat resah para pekerja sosial waktu itu. Atas dasar ini, mereka berusaha dengan giat untuk mengembangkan landasan ilmu pengetahuannya. Kebetulan pada waktu itu di Amerika mulai dikembangkan ajaran Sigmund Freud tentang psikoanalisa. Para pekerja sosial yang mengikuti kuliah psikoanalisis ini merasa bahwa pengetahuan ini dapat diterapkan dalam pekerjaan sosial. Para pekerja sosial lain juga berusaha mencari landasan ilmu pengetahuan lain yang dapat memerkuat status pekerjaan sosial sebagai profesi (Fahrudin, 2012a).

Dalam tahun 1957, Ernest Greenwood menulis artikel tentang atribut suatu profesi. Kriteria profesi yang dikemukakan oleh Greenwood adalah sebagai berikut:

1. Suatu profesi memunyai pengetahuan dasar dan mengembangkan sekumpulan teori yang sistematik yang mengarahkan ketrampilan-ketrampilan praktik; persiapan pendidikan haruslah bersifat intelektual maupun praktikal.

2. Kewenangan dan kredibilitas dalam hubungan klien-tenaga profesional didasarkan atas penggunaan pertimbangan dan kompetensi profesional.

3. Suatu profesi diberi kekuatan untuk mengatur dan mengontrol keanggotaan, praktik profesional, pendidikan, dan standar kinerjanya sendiri. Masyarakat membenarkan kekuatan-kekuatan pengaturan dan hak-hak istimewa profesional.

4. Suatu profesi memunyai kode etik pengaturan yang mengikat, yang dapat ditegakkan, eksplisit, dan sistematik yang memaksa perilaku etik oleh anggota-anggotanya.

5. Suatu profesi dibimbing oleh budaya nilai-nilai, norma-norma, dan simbol-simbol dalam suatu jaringan organisasi dari kelompok-kelompok formal dan informal, sebagai saluran untuk profesi itu berfungsi dan melaksanakan pelayanan-pelayanannya. (dalam DuBois \& Miley, 2005).

Dengan mencermati lima kriteria tersebut, nampak bahwa ciri-ciri profesi telah menjadi ciri yang melekat pada profesi pekerjaan sosial. Sebagai suatu profesi yang sedang berkembang di Indonesia, pekerjaan sosial harus merebut public trust melalui peningkatan mutu kinerja pekerja sosial. Tanpa public trust sangatlah sukar untuk mengokohkan identitas profesi dalam masyarakat. Kekuatan dan eksistensi pekerjaan sosial hadir sebagai resultant interaksi simbiosis antara kinerja pekerja sosial dan public trust tadi.

Pekerjaan sosial sebagai profesi memunyai empat unsur utama, yang pada umumnya, tiga unsur di antaranya dikatakan sebagai pengetahuan, sikap, dan ketrampilan. Tetapi kalau kita teliti lebih jauh, sikap dan ketrampilan sudah bersatu dengan individunya, sedangkan pengetahuan terlepas dari individu. Sikap adalah kecenderungan yang relatif bertahan lama dari seorang individu untuk mengamati, merasakan, berfikir, dan bertindak dalam suatu cara tertentu terhadap suatu objek tertentu (Komorita, Neel, \& Wagman, 1962). Sedangkan ketrampilan adalah kemahiran dalam menerapkan pengetahuan dan dalam menggunakan metode dan teknik tertentu. 
Kalau unsur-unsur tersebut akan dipisahkan dari orangnya, maka unsur-unsur tersebut menjadi "pengetahuan," "nilai-nilai" yaitu yang mendasari sikap, dan "metode serta teknik" yang akan digunakan dalam proses pertolongan. Hal ini sejalan dengan definisi kerja 'praktik pekerjaan sosial' yang komponennya secara lengkap adalah: nilai, maksud atau misi, sanksi yang berarti kewenangan untuk melaksanakan praktik, pengetahuan dan metode (Bartlett, 1988). Hepworth, Rooney, dan Larsen (2002) juga menyatakan bahwa unsur-unsur inti yang mendasari pekerjaan sosial di manapun dipraktikkan adalah sebagai berikut; (1) Maksud/tujuan profesi itu, (2) Nilai-nilai dan etika, (3) Dasar pengathuan praktik langsung, (4) Metode-metode dan proses-proses yang dilakukan. Dengan demikian seseorang yang memasuki lembaga pendidikan pekerjaan sosial akan memelajari pengetahuan, nilainilai serta etika, dan metode serta teknik pekerjaan sosial dari lembaga pendidikan tersebut. Setelah semua itu dipelajari dan dikuasai, maka dalam diri calon pekerja sosial ini akan terbentuk "kemampuan melakukan analisis" (dilandasi oleh pengetahuan), "sikap" (dilandasi oleh nilai-nilai yang diyakini dan dianut), dan "ketrampilan" (dilandasi oleh metode dan teknik yang telah dipelajari dan dikuasai). Dengan berpedoman pada ilmu pengetahuan yang telah dipelajarinya, serta dibimbing oleh nilai-nilai yang dianutnya, pekerja sosial menggunakan ketrampilannya dalam membantu individu, kelompok atau masyarakat. Praktik pekerjaan sosial dilaksanakan dalam dua cara, yaitu secara langsung berhadapan dengan klien, baik secara individual maupun dalam kelompok, dan secara tidak langsung berhadapan dengan klien, dalam arti memusatkan perhatian pada institusi kesejahteraan sosial, pada lembaga-lembaga atau organisasi kesejahteraan sosial, pada evaluasi, analisis, perumusan dan pengembangan program-prgram kesejahteraan sosial. Pendekatan praktik semacam ini kadang-kadang disebut juga sebagai jalur klinis dan jalur pengembangan sosial; pelayanan pada individu, keluarga, dan kelompok, dan pelayanan pengembangan sosial; pelayanan mikro dan makro. Tetapi penggunaan istilah praktik langsung (direct practice) dan praktik tidak langsung (indirect practice) lebih umum digunakan dalam pekerjaan sosial (Gilbert, Miller, \& Specht, 1980). Berdasarkan uraian di atas jelaslah bahwa pekerjaan sosial merupakan profesi berbasis praktik. Intinya pada praktik, tapa praktik maka bukanlah profesi. Profesi adalah pekerjaan yang dibayar, dan profesi memerlukan pendidikan dan pelatihan lanjutan. Oleh karena profesi tidak hanya mengatur urusan internal pelaku profesi tapi juga berurusan dengan perlindungan pengguna profesi maka sebauh profesi seperti pekerjaan sosial tidak cukup dengan Kode Etik Profesi namun memerlukan perlindungan oleh negara melalui UndangUndang Pekerjaan Sosial sepertimana Republic Act No. 4373 Tahun 1965 yang dikenali sebagai Social Work Law di Philippines, Enactment Of The Certified Social Worker and Certified Care Workers' Law Revision 2007 di Jepang, atau Social Work Amandement Act 1998 di Afrika Selatan.

\section{Kesimpulan}

Pekerjaan sosial merupakan disiplin akademik dan profesi berbasis praktek. Sebagai disiplin ilmu sosial terapan, pekerjaan sosial bersumber dari teori-teori pekerjaan sosial itu sendiri, ilmu-ilmu sosial lain, humaniora, dan pengetahuan lokal. Pekerjaan sosial juga merupakan sebuah profesi pelayanan kemanusiaan berlandaskan teori/ilmu pengetahuan yang telah teruji melalui penelitian dan dipraktikan (evidence based practice). Syarat sebuah profesi harus mencakup empat unsur utama, pengetahuan, sikap, ketrampilan, dan metode dan teknik tertentu dalam menjalankan profesi tersebut. Untuk melahirkan pekerja sosial professional perlu melalui pendidikan pekerjaan sosial secara formal, terstruktur dan dididik oleh ahli akademik pekerjaan sosial dengan berpandu kepada standar global pendidikan pekerjaan sosial yang dikeluarkan oleh IASSW dan IFSW.

\section{Rujukan}

Barker, R.L.(1987). The social work dictionary. Washington DC: NASW Press.

Bartlett, H. (1958). Toward clarification and improvement of social work practice. Social Work, $6(2), 3-9$

Beckner, M. (1967). Teleology. In P..Edwards (Ed.), Encyclopedia of philosophy (vol. 8, pp.88-91). New York: McMillan 
Dubois, B. \& Miley, K. K. (2005). Social Work: An Emporing Profession (5 ${ }^{r d}$. ed.). Boston: Allyn and Bacon.

Fahrudin, A. (2013a). Social welfare and social work in Indonesia. Dalam Sharlene B.C.L.Furuto (Ed.), Social welfare in East Asia and the Pacific. New York: Columbia University Press.

Fahrudin, A. \& Husmiati Yusuf. (2013). Internationalization of social work education in Indonesia: The case of the Bandung College of Social Welfare. Dalam Tatsuru Akimoto \& Kana Matsuo (Eds.), Internationalization of Social Work Education in Asia. Tokyo: Institute of Social Work Research and Asian and Pacific Association for Social Work Education.

Fahrudin, A. (2012a). Pengantar kesejahteraan sosial. Bandung: PT Refika Aditama.

Fahrudin, A. (2012b). Kesejahteraan sosial internasional. Bandung: CV Alfabeta.

Fahrudin, A. (2003a). Menuju piawaian praktis kerja sosial di Malaysia. Bahan edaran untuk perbincangan dalam Malaysian Joint Commission on Social Work Education Meeting and Advance Indigenous Social Work Conference anjuran Social Work Program, Faculty of Social Sciences, Universiti Malaysia Sarawak, 20-23 Oktober 2003.

Fahrudin, A. (2003b). Pendidikan dan latihan kerja sosial dan piawaian praktis kerja sosial di Malaysia. Buletin Psikologi, Bil. 8/Tahun 2003. Kota Kinabalu: Sekolah Psikologi dan Kerja Sosial, Universiti Malaysia Sabah.

Fahrudin, A. (2003c). Menuju standar praktek pekerjaan sosial di Indonesia: Pokok-pokok pikiran untuk bahan diskusi. Cipayung, Bogor, 19 Maret 2003.

Fahrudin, A. (2002). Direction for social work education. Paper presented at Academic Retreat Program. Kota Kinabalu: School of Psychology and Social Work, Universiti Malaysia Sabah.

Fahrudin, A. (2000a). Social work education, professional commitment, and the future of social work practice in Malaysia. Paper presented at National Conference on Social Work, Organized by Northern University of Malaysia, $26^{\text {th }}-27^{\text {th }}$ January 2000.

Fahrudin, A. \& Othman, A.H. (2000b). Social Work Education in Universiti Malaysia Sabah: A social work curriculum structure at bachelor level. Paper presented at Round table conference on Social Work Education in Malaysia, September 2000, Universiti Sains Malaysia.

Fahrudin, A. (1997). Pendidikan tinggi pekerjaan sosial: Sejarah, agenda masalah dan kegayutannya dengan pembangunan nasional. Dalam Prosiding Seminar Ilmiah Perhimpunan Pelajar Indonesia (PPI) se - Malaysia. Penang: Perhimpunan Pelajar Indonesia, Universiti Sains Malaysia.

Farley, W.O., Smith, L.L. \& Boyle, S.B. (2003). Introduction to Social Work. Pearson

Gordon, W.E. (1983). Social work revolution or evolution. Social Work, 28, 181-185.

Gilbert, N., Miller, H. \& Specht, H. (1980). Introduction to social work. Englewood Cliff, New Jersey: Prentice-Hall,inc.

Greenwood, E. (1957) “Attributes of a profession,” Social Work, 2, 5-45.

Hepworth, D. H. , \& Larsen, J. A. (1982). Direct Social Work Practice: Theory and Skills. Homewood, 111: The Dorsey Press

Hornby, G. (1995). Working with parents of children with special needs. London: Cassell.

International Federation of Social Workers (2015). Definition of social work: English version. IFSW

General Meeting, 10-12 July 2014, diakses tanggal 22 Juli 2015International Federation of Social

Workers (2000). Definition of social work: English version. IFSW General Meeting, 25-27 July 2000, http://www.ifsw.org/Publications/diakses tanggal 2 November 2013

Miley, K.K., O’Melia, M., \& L.DuBois,B. (1995). Generalist social work practice : An Empowering approach. Boston : Allyn and Bacon.

National Association of Social Workers (NASW). (2013). http://www.socialworkers.org diakses tanggal 2 November 2013

Payne, M. (1995). Modern theory in social work. London: Heineman

Richmond, M.E. (1917). Social diagnosis. New York, NY: Russell Sage Foundation. https://www.questia.com/read/94922954/social-diagnosis

Siporin, M. (1975). Introduction to social work practice. New York: McMillan.

Skidmore, A. R. \& Thackeray, G.M. (1982). Introduction to Social Work [3th..ed]. Englewood Cliff. New Jersey : Prentice-Hall, Inc.

Soufle'e, F. Jr. (1993). A Metatheoreical framework for Social Work Practice. Dalam Social Work, 38(3), 317-331. 
Stone, E.F. (1979). Research method and philosophy of science. I S.Kerr (Ed.), Organizational behavior (pp.15-40), Columbus, OH: Grid.

Taylor, J.C. (1971). Technology and planned organizational change. Ann Arbor: University of Michigan Institute of Social Research.

Webster's II New College Dictionary. (1995). Boston: Houghton Mifflin Harcourt

Zastrow, C. (1999). Introduction to Social Work and Social Welfare: Empowering People. Pacific Grove, California: Brooks/Cole Publishing Company 